\title{
EFEKTIVITAS PELAYANAN KELILING ONLINE PADA DINAS KEPENDUDUKAN DAN PENCATATAN SIPIL KABUPATEN TANAH DATAR
}

\author{
Wingfi Japami \\ Jurusan Administrasi Publik, Fakultas Ilmu Sosial, Universitas Negeri Padang \\ wingfijapami@gmail.com \\ Fitri Eriyanti \\ Jurusan Administrasi Publik, Fakultas Ilmu Sosial, Universitas Negeri Padang \\ fitri.eriyanti4138@gmail.com
}

\begin{abstract}
Since the enactment of the policy on the implementation of active systems, employees are required to provide direct services to the public. Online mobile service is a service activity that is carried out by the Population and Civil Registration Service of Tanah Datar District by visiting Nagari in Tanah Datar District. This activity in its implementation still encountered various problems, like in some areas there are only a few people because they do not know the requirements, service time that is not enough, inadequate service places and facilities, as well as internet network constrains. This study aims to analyze the effectiveness of online mobile services, find out the factors that influence and to find out about the efforts in which are committed in increasing the effectiveness of online mobile services. The method that is used is descriptive method with qualitative approach. The data that is used for this study are primary and secondary data, collected through interviews, observation and documentation studies. The results of the study indicate that the goals achievement in this service has not been comprehensive, it shows that the achievement of overall goals is weak and it is resulting in less effective mobile online services. Then, there are existed obstacles related to low public awareness, lack of socialization and internet network problems.
\end{abstract}

Keywords: Effectiveness, Publik Service, Online Mobile Service 
$\overline{\text { jmiap.ppj.unp.ac.id }}$

\section{PENDAHULUAN}

Pembukaan

UUD

1945

mengamanatkan bahwa tujuan didirikan Negara Republik Indonesia adalah untuk memajukan kesejahteraan umum dan mencerdaskan kehidupan bangsa. Amanat tersebut mengandung makna bahwa negara berkewajiban memenuhi kebutuhan setiap warga negara melalui suatu sistem pemerintahan yang mendukung terciptanya penyelenggaraan pelayanan publik yang prima. Pelayanan publik dapat dimaknai sebagai aktivitas pelayanan yang dilakukan oleh lembaga pemerintah untuk memenuhi kebutuhan masyarakat (Mulyadi, 2016).

Penyelenggaraan pelayanan publik merupakan upaya negara untuk memenuhi kebutuhan dasar dan hak-hak sipil setiap warga negara atas barang publik, jasa publik, dan pelayanan administratif. Sehingga efektivitas suatu sistem pemerintahan sangat ditentukan oleh baik buruknya penyelengaraan pelayanan publik. Efektivitas suatu pelayanan yang diberikan oleh aparat pemerintah sangat dipengaruhi oleh faktor-faktor yang mendukung maupun menghambat tercapainya tujuan dari pelayanan suatu organisasi kepada masyarakat. Dicson dan Wetherbe dalam (Samsudin, 2014) mengatakan bahwa ada beberapa faktor yang mempengaruhi efektivitas pelayanan, yaitu: kualitas aparatur, kompetensi administrator, disiplin, sarana dan prasarana serta pengawasan.

Konsep efektivitas merupakan konsep yang luas, mencakup berbagai faktor di dalam maupun di luar organisasi. Efektivitas adalah ukuran berhasil tidaknya pencapaian tujuan suatu kegiatan. Apabila suatu kegiatan berhasil mencapai tujuan, maka kegiatan tersebut telah berjalan dengan efektif (Jauhar, 2013). Efektifitas digunakan sebagai tolak ukur untuk membandingkan antara rencana dan proses yang dilakukan dengan hasil yang dicapai. Sehingga untuk menetukan efektif atau tidaknya suatu program maka diperlukan

\section{Email : jianfis.unp@gmail.com}

Vol.2 No.1 Maret 2019

ukuran-ukuran efektifitas. Terdapat cara pengukuran efektifitas secara umum yang digunakan dalam penelitian ini yaitu keberhasilan program, keberhasilan sasaran, kepuasan terhadap program, tingkat input dan output, dan pencapaian tujuan menyeluruh (Campbell, 1989).

Salah satu bentuk pelayanan yang diberikan oleh pemerintah adalah pelayanan administrasi di bidang kependudukan, meliputi pelayanan terhadap peristiwa penting dan peristiwa kependudukan yang diatur dalam UndangUndang Nomor 24 Tahun 2013 tentang Administrasi Kependudukan. Sebagai suatu sistem bagi penduduk diharapkan dapat memberikan pemenuhan atas hak-hak administratif penduduk dalam pelayanan publik, serta memberikan perlindungan yang berkenaan dengan penerbitan dokumen kependudukan tanpa ada perlakuan yang diskriminatif.

Pada Kabupaten Tanah Datar terkait administrasi kependudukan dan pencatatan sipil dilakukan oleh Dinas Kependudukan dan Pencatatan Sipil Kabupaten Tanah Datar. Sesuai dengan Peraturan Daerah Kabupaten Tanah Datar nomor 09 tahun 2010 tentang Pembentukan Organisasi dan tata Kerja Dinas Daerah di Lingkungan Pemerintah Kabupaten Tanah Datar. Serta Peraturan Bupati Tanah Datar nomor 46 tahun 2011 tentang uraian tugas Dinas Kependudukan dan Pencatatan Sipil Kabupaten Tanah Datar, bahwa tugas pokok dan fungsi Dinas Kependudukan dan Pencatatan Sipil Kabupaten Tanah Datar adalah membantu Bupati dalam bidang pembangunan administrasi kependudukan.

Dinas Kependudukan dan Pencatatan Sipil Kabupaten Tanah Datar telah mendapat apresiasi dari Tim Penilai Provinsi Sumatera Barat. Selama ini pelayanan birokrasi dicap jelek oleh masyarakat, namun pelayanan birokrasi dan administrasi kependudukan Pemerintah Kabupaten Tanah Datar sudah bagus. Dinas 
Kependudukan dan Pencatatan Sipil Kabupaten Tanah Datar telah berupaya semaksimal mungkin untuk memberikan pelayanan yang terbaik dan seefektif mungkin bagi masyarakat melalui inovasiinovasi yang terus dikeluarkan untuk memudahkan pemberian pelayanan. Salah satu inovasi adalah pelayanan dengan sistem jemput bola atau yang dikenal dengan nama pelayanan keliling online ke Nagari-nagari yang ada di Kabupaten Tanah Datar. Dalam pelayanan ini semua dokumen dapat langsung dicetak di lokasi pelayanan, tanpa dipungut biaya dengan catatan semua bahan persyaratan lengkap.

Dalam pelaksanaannya menunjukkan
bahwa penyelenggaraan kegiatan pelayanan keliling online yang dilakukan oleh Dinas Kependudukan dan Pencatatan Sipil Kabupaten Tanah Datar masih menemui berbagai permasalahan. Pelaksanaan kegiatan masih belum efektif, dimana pada hari pertama pelayanan masyarakat yang datang cenderung sedikit karena belum mengetahui persyaratan dan prosedur, sehingga pada hari kedua dan ketiga terjadi lonjakan jumlah masyarakat yang melakukan pelayanan. Jangka waktu pelayanan selama 3 (tiga) hari masih dirasa kurang cukup, sehingga terkadang waktu pelayanan ditambah sampai menjelang waktu magrib dan jika memang tidak memungkinkan untuk dilanjutkan maka dokumen masyarakat terpaksa harus dibawa ke kantor untuk di proses. Permasalahan koneksi internet membuat kegiatan pelayanan tidak bisa dilaksanakan, bahkan harus berpindah tempat ke lokasi yang terdapat koneksi internetnya. Keterbatasan tempat, belum tersedianya fasilitas tempat duduk dan pendingin ruangan bagi masyarakat yang menunggu, masyarakat yang tidak mengerti tata cara pengisisan formulir untuk pelayanan, dan masih kuatnya asumsi masyarakat bahwa dokumen kependudukan dirasa tidak penting atau belum perlu untuk dilakukan pengurusan.
Email : jianfis.unp@gmail.com Vol.2 No.1 Maret 2019

Penelitian ini bertujuan untuk menganalisis efektivitas pelayanan keliling online, mengetahui faktor-faktor yang mempengaruhi efektivitas pelayanan keliling online, dan untuk mengetahui upaya yang dilakukan oleh Dinas Kependudukan dan Pencatatan Sipil Kabupaten Tanah Datar dalam meningkatkan efektivitas pelayanan keliling online.

\section{METODE PENELITIAN}

Jenis penelitian ini adalah kualitatif dengan menggunakan metode deskriptif. Penelitian dilakukan di kantor Dinas Kependudukan dan Pencatatan Sipil Kabupaten Tanah Datar, Nagari Pangian Kecamatan Lintau Buo, dan di Nagari Sungayang Kecamatan Sungayang Kabupaten Tanah Datar. Pemilihan informan dalam penelitian ini menggunakan teknik purposive sampling. Kriteria informan yang diambil adalah instansi pemerintah yang bertanggung jawab dalam pelaksanaan pelayanan keliling online, yaitu pegawai Dinas Kependudukan dan Pencatatan Sipil Kabupaten Tanah Datar, dan masyarakat yang terlibat dalam pelayanan di Nagarinagari tempat pelayanan keliling online berlangsung. Data yang digunakan adalah data primer dan data sekunder. Data primer diperoleh melalui wawancara dan observasi langsung dari informan. Data sekunder diperoleh melalui studi dokumentasi terhadap literatur yang dapat menunjang penelitian.

Untuk mendapatkan data yang kredibilitas tinggi maka dalam penelitian ini digunakan bentuk pemeriksaan keabsahan data yang sesuai dengan pendapat (Moleong, 2012), yaitu teknik triangulasi sumber yang dilakukan dengan cara melakukan member check sampai dicapai tahap kejenuhan data. Proses analisis data dimulai dengan pengumpulan data, reduksi data, penyajian data, dan terakhir penarikan kesimpulan. 


\section{HASIL DAN PEMBAHASAN}

a. Efektivitas Pelayanan Keliling Online pada Dinas Kependudukan dan Pencatatan Sipil Kabupaten Tanah Datar

Adapun untuk melihat efektivitas pelayanan keliling online pada Dinas Kependudukan dan Pencatatan Sipil Kabupaten Tanah Datar, dilihat dengan menggunakan indikator efektivitas seperti yang dikemukakan oleh (Campbell, 1989), yang terdiri dari:

\section{1) Keberhasilan Program}

Program pelayanan keliling online bertujuan untuk mendekatkan pelayanan kepada masyarakat dalam upaya percepatan kepemilikan dokumen kependudukan, yang apabila dalam pelaksanaan program ini dapat berjalan dengan baik maka dapat berdampak pada keberhasilan program tersebut, sehingga program dapat efektif. Berdasarkan temuan penelitian dapat diketahui bahwa program pelayanan keliling online tidak sepenuhnya efektif. Hal ini ditandai dengan ditemuinya permasalahan pada rendahnya kesadaran masyarakat untuk mengurus dokumen kependudukan dan permasalahan bagi masyarakat yang sudah tua dan sakit-sakitan sehingga tidak bisa datang ke kantor untuk melakukan perekaman data KTP-el, permasalahan tersebut tentu berdampak pada tingkat pencapaian target dari pelayanan ini.

Pada dasarnya kesadaran itu datang dari diri dalam pribadi masyarakat sendiri yang merasa tahu dan mengerti akan pentingnya dokumen kependudukan. Namun tidak dapat dipungkiri bahwa masih banyak masyarakat yang tidak melakukan pengurusan dokumen kependudukan
Email : jianfis.unp@gmail.com Vol.2 No.1 Maret 2019

seperti merasa tidak membutuhkan, merasa belum memerlukan, bahkan masyarakat yang sama sekali tidak peduli dengan dokumen kependudukan. Hal ini disebabkan beberapa hal yang salah satunya masyarakat belum mendapatkan informasi atau penyuluhan dari pemerintah tentang peran penting dari kepemilikan dokumen kependudukan.

Kemudian pada proses sosialisasi yang masih kurang berujung kepada tidak meratanya penyebaran informasi yang diterima masyarakat mengenai pelayanan ini, sehingga saat pelayanan dilakukan hanya sedikit masyarakat yang datang melakukan pelayanan. Sedangkan sosialisasi sangat dibutuhkan dalam membantu dalam keberhasilan program ini. Dengan sosialisasi masyarakat akan mendapatkan informasi, konsultasi dan bimbingan mengenai pentingnya dokumen kependudukan guna meningkatkan pengetahuan, kesadaran dan kemauan masyarakat untuk memperoleh hak dan melaksanakan kewajiban kependudukan.

\section{2) Keberhasilan Sasaran}

Sasaran dari pelayanan keliling online yaitu daerah yang angka kepemilikan dokumen kependudukannya masih rendah dan daerah yang berada jauh dari lokasi kantor. Berdasarkan temuan menunjukkan bahwa sasaran dari pelayanan keliling online ini telah tercapai dari segi dinas telah melakukan pelayanan langsung ke nagari. Dengan mendekatkan pelayanan kepada masyarakat dapat memotong jalur birokrasi pelayanan, sehingga masyarakat dapat lebih mudah mengakses pelayanan dan kualitas pelayanan pun menjadi lebih baik bagi masyarakat. 
Sehingga program ini dianggap dapat memberikan akses yang baik dan menciptakan keseimbangan antara pemerintah dan masyarakat, yaitu dengan pengurusan dokumen kependudukan yang lebih mudah dan terjangkau. Adanya program ini masyarakat tidak perlu jauh-jauh untuk mengurus dokumen kependudukan ke kantor, mengingat setiap kecamatan yang ada di Kabupaten Tanah Datar ini secara geografis letaknya berjauhan, sehingga relatif sulit mendapatkan akses pelayanan.

Tetapi disisi lain masih terdapat permasalahan jaringan internet yang membuat pelayanan terkendala untuk dilakukan. Hal ini disebabkan oleh kondisi wilayah, karena daerah perdesaan terkadang jaringan internet tidak bagus di lokasi pelayanan. Sebagaimana menurut (Adaniah, 2016) mengatakan dalam mengamati dampak positif dari internet pemerataan pembangunan perlu dilakukan. Tidak hanya di daerah perkotaan tetapi juga perdesaan, karena pembangunan infrastruktur internet memungkinkan masyarakat wilayah perdesaan untuk berkomunikasi, mengakses dan memperoleh informasi melalui berbagai layanan atau aplikasi sehingga dapat memberikan dampak ekonomi bagi masyarakat. Lemahnya koneksi internet disebabkan oleh infrastruktur internet di wilayah tersebut masih tertinggal dan minim. Sehingga ketika jaringan internet lemah maka proses pelaksanaan pelayanan juga akan terkendala. Hal diatas menunjukkan bahwa indikator pencapaian sasaran program ini belum efektif karena tidak tercapainya sasaran secara menyeluruh dan masih adanya kendala yang terjadi.

\section{3) Kepuasan Terhadap Program}

Email : jianfis.unp@gmail.com Vol.2 No.1 Maret 2019

Kepuasan merupakan kriteria efektivitas yang mengacu pada keberhasilan program dalam memenuhi kebutuhan pengguna. Berdasarkan temuan penelitian terlihat bahwa masyarakat telah puas dengan program ini. Kepuasan masyarakat tersebut terlihat dari masyarakat senang karena pelayanan ini mendekatkan pelayanan kepada masyarakat sehingga dapat menolong masyarakat untuk lebih mudah memperoleh dokumen kependudukan.

Hasil penelitian diatas sesuai dengan pendapat (Ibrahim, 2008) bahwa kualitas pelayanan diartikan sebagai sesuatu yang berhubungan dengan terpenuhinya harapan/kebutuhan pelanggan (masyarakat), dimana pelayanan dikatakan berkualitas apabila dapat menyediakan produk yang sesuai dengan kebutuhan masyarakat. Jadi ketika kebutuhan masyarakat tersebut dapat terpenuhi melalui pelayanan ini tentu masyarakat menjadi puas terhadap pelayanan.

Selain itu melalui pelayanan ini masyarakat tidak perlu lagi jauh-jauh datang ke kantor di Batusangkar, sehingga merasa dimudahkan segi waktu dan biaya jika dibandingkan dengan datang ke kantor. Kemudian kepuasan masyarakat juga timbul karena dokumen yang diurus dapat langsung diterbitkan di lokasi pelayanan. Masyarakat juga puas dikarenakan prosedur untuk mendapatkan pelayanan tidaklah berbelit-belit dan tidak membutuhkan waktu lama. Disisi lain kepuasan masyarakat dapat dibuktikan dengan adanya permintaan dari Nagari-nagari untuk dilakukan pelayanan keliling online di tempatnya.

Dari pemaparan diatas dapat dikatakan bahwa masyarakat telah merasa puas dengan program ini karena 
Email : jianfis.unp@gmail.com Vol.2 No.1 Maret 2019

masyarakat merasa senang dan terbantu. Kemudian puas karena dokumen dapat langsung diterima dalam waktu yang cepat.

\section{4) Tingkat Input dan Output}

Pada efektivitas tingkat input dan output dapat dilihat dari perbandingan antara masukan (input) dengan keluaran (output). Jika output lebih besar dari input maka dapat dikatakan efektif dan sebaliknya jika input lebih besar dari output maka dapat dikatakan tidak efektif. Dari temuan penelitian diketahui bahwa dalam program ini jika dilihat dari segi input cukup baik, hal ini ditandai dengan dinas sebagai pihak pelaksana telah menyediakan segala sumber daya yang diperlukan, seperti sumber daya manusia, mobil untuk pelayanan, serta segala peralatan dan perlengkapan untuk menunjang pelayanan sehingga kegiatan pelayanan dapat dilaksanakan.

Tetapi input belum sesuai dengan output karena dipengaruhi oleh faktor keadaan di lapangan seperti dibeberapa nagari ada yang masyarakatnya ramai dan ada juga nagari yang sedikit masyarakatnya datang saat pelayanan, sehingga membuat output tersebut tidak kelihatan. Hal tersebut disebabkan oleh penyebaran informasi kepada masyarakat mengenai pelayanan belum menyeluruh. Sedangkan dalam semua kegiatan yang dilakukan memerlukan informasi. Oleh karena itu informasi berguna untuk semua macam dan bentuk kegiatan yang akan dilakukan. Karena dengan penyebaran informasi yang baik akan menyediakan informasi yang lengkap bagi masyarakat mengenai pelayanan ini.

Dalam manfaat dan peranan informasi dinas dapat melakukan kerja sama dengan pemerintah Nagari sehingga dapat mendukung pencapaian tujuan. Dalam pelayanan ini dari segi input pelayanan ini sudah tersedia, tetapi output yang diharapkan tidak sesuai dengan input yang besar tadi. Jadi ketika output yang diperoleh kecil maka otomatis tingkat efektivitasnya juga lemah.

\section{5) Pencapaian Tujuan Menyeluruh}

Efektifitas program dapat dijalankan berdasarkan dengan kemampuan operasionalnya dalam melaksanakan program yang sesuai dengan tujuan yang telah tetapkan sebelumnya. Untuk melihat seberapa besar pencapaian tujuan secara menyeluruh dari pelayanan keliling online ini dapat dilihat dari temuan penelitian bahwa pelayanan ini dapat membantu dalam percepatan pencapaian target kepemilikan dokumen kependudukan, yang terlihat dari tingkat pencapaian target dinas yang terus meningkat disetiap tahunnya. Namun pencapaian tujuan menyeluruh dalam realisasi pelayanan keliling online ini tidak sepenuhnya berhasil. Dimana melalui program ini target baru tercapai kurang lebih separuh dari target pencapaian, untuk dokumen kependudukan KTP-el dan KK sudah mendekati target, namun untuk Akta Kelahiran masih jauh dari target. Dapat disimpulkan bahwa ketika pencapaian program ini tidak mencapai target maka pencapaian tujuan tidak secara menyeluruh tercapai.

Selain itu yang menjadi kendala dalam pencapaian tujun adalah masyarakat yang tidak mengetahui persyaratan sehingga saat pelayanan persyaratan tidak lengkap dan pelayanan tidak dapat di proses. Kemudian terkait kurangnya pemahaman masyarakat dalam melakukan pengisisan formulir untuk melakukan pelayanan sehingga seringkali terjadi kesalahan dalam pengisian formulir. Dalam hal dokumen milik masyarakat yang saling tumpang 
tindih, seperti data nama atau tanggal lahir yang berbeda antara ijazah dengan KK atau dengan buku nikah.

Permasalahan lain yaitu kendala dari dinas yaitu anggaran biaya yang masih kurang, masih diperlukan biaya untuk melengkapi peralatan penguat jaringan internet dan biaya untuk melakukan kegiatan sosialisasi. Permasalahan kondisi daerah karena perdesaan seringkali jaringan internet lemah dibeberapa Nagari sehingga dapat menghambat pelaksanaan kegiatan. Selain itu masalah rendahnya kesadaran masyarakat yang disebabkan oleh rendahnya tingkat pendidikan masyarakat juga mempengaruhi tingkat pencapaian tujuan dalam program ini. Jadi dari penjelasan diatas, jika ditanya pencapaian tujuan menyeluruh dapat dikatakan program ini tidak efektif karena masih belum mencapai tujuan dalam percepatan pencapaian target kepemilikan dokumen kependudukan.

\section{b. Faktor-faktor yang mempengaruhi Efektivitas Pelayanan Keliling Online Pada Dinas Kependudukan dan Pencatatan Sipil Kabupaten Tanah Datar}

Dalam pelaksanaan suatu program tentu ada faktor-faktor yang mempengaruhi tingkat pencapaian tujuan dari program tersebut. Dalam penelitian ini penulis memakai teori dari Dicson dan Wetherbe dalam (Samsudin, 2014) mengatakan bahwa ada beberapa faktor yang mempengaruhi efektivitas pelayanan, yaitu:

\section{1) Kualitas Aparatur}

Kualitas sumber daya aparatur adalah tingkat pendidikan dan pelatihan, pengalaman, dan kinerja yang dmiliki oleh aparatur dalam melaksanakan aktivitas-aktivitas yang menjadi tanggung jawab anggotanya untuk mencapai tujuan organisasi. Dalam pelayanan keliling ini petugas
Email : jianfis.unp@gmail.com Vol.2 No.1 Maret 2019

yang akan melakukan pelayanan tidak diberikan pendidikan dan pelatihan, karena tugas yang akan dilakukan di lapangan sama dengan di kantor. Jadi pada dasarnya semua petugas sudah mengetahui tentang pekerjaan tersebut. Namun disisi lain masih terdapat permasalahan yaitu manajemen pengelolaan antara petugas yang pergi dan yang tinggal masih belum seimbang, krena petugas yang pergi ke lapangan terlalu banyak membuat pelayanan di kantor menjadi kekurangan petugas. Hal tersebut juga menimbulkan pengaruh terhadap berhasil atau tidaknya organisasi dalam melaksanakan tugas.

Selain itu target kinerja dalam pelayanan ini adalah menghasilkan 100-150 dokumen kependudukan dalam waktu 5 jam, akan tetapi karena kondisi masyarakat yang tidak peduli dengan pelayanan ini maka target terkadang tidak dapat tercapai sepenuhnya. Jika masyarakatnya acuh dan tidak peduli dengan pelayanan tentu saat pelayanan dilakukan masyarakat yang datang hanya sedikit sehingga target tidak bisa tercapai. Namun jika tingkat partisipasi masyarakatnya tinggi maka target akan tercapai, hal ini juga dipengaruhi oleh faktor tingkat kesadaran masyarakat dan tingkat penerimaan informasi bagi masyarakat mengenai pelayanan ini. Jadi dapat karena target kinerja yang belum dapat tercapai, ini berpengaruh kepada tujuan realisasi pelayanan keliling online yang tidak dapat tercapai secara menyeluruh.

\section{2) Kompetensi Administrator}

Kompetensi yaitu kemampuan kerja setiap individu yang mencakup aspek pengetahuan, keterampilan, serta di dukung oleh sikap kerja yang sesuai dengan standar yang ditetapkan. Dari temuan penelitian, penulis mendapati kompetensi administrator sudah bagus 
Email : jianfis.unp@gmail.com Vol.2 No.1 Maret 2019

yang ditandai dengan petugas yang melakukan pelayanan ini sudah memiliki pengetahuan mengenai tugasnya, karena penempatan petugas sesuai bidang masing-masing seperti di kantor. Pengetahuan petugas dalam menjalankan tugasnya sangat berpengaruh terhadap keberlangsungan kerja petugas tersebut. Hal ini juga membantu organisasi lebih mengetahui posisi apa yang cocok dan tepat untuk petugas tersebut, agar dalam pelaksanaannya kinerja petugas menjadi baik dan pada akhirnya juga berpengaruh kepada produktivitas organisasi.

Kemudian sikap petugas dalam melayanani mesyarakat juga sudah baik, sehingga masyarakat merasa senang dan puas dalam pelayanan ini. Sesuai dengan pendapat (Hutapea, 2008) bahwa sikap merupakan pola tingkah laku seorang karyawan/pegawai di dalam melaksanakan tugas dan tanggung jawabnya sesuai dengan peraturan organisasi, sehingga dengan sikap petugas dalam melayani masyarakat bisa menilai apakah sikap tersebut sudah baik atau belum. Dalam pelayanan ini masyarakat mengungkapkan bahwa sikap petugas pelayanan keliling online sudah baik, karena petugas bersikap baik dan ramah dalam melayani masyarakat. Sikap seperti itulah yang membuat masyarakat menjadi senang dan nyaman dalam melakukan pelayanan sehingga masyarakat juga menjadi puas terhadap pelayanan. Dapat dikatakan bahwa kompetensi dan sikap dari para petugas sebagai pelaksana dari program adalah hal yang penting diperhatikan karena dapat memberikan pengaruh yang sangat besar dalam pencapaian tujuan program.

\section{3) Disiplin}

Disiplin menyangkut dengan tingkat kepatuhan dan ketaatan kepada aturan yang berlaku. Berdasarkan temuan penelitian, antara pegawai dinas dan masyarakat menggambarkan adanya perbedaan persepsi dari kedua belah pihak tersebut. Pegawai dinas mengatakan bahwa petugas berangkat menuju lokasi pada pukul 08.00 setelah melakukan apel pagi dan pelayanan umumnya di mulai pada pukul 09.00. Sedangkan masyarakat sebagai objek dari program ini mengutarakan hal berbeda dengan mengatakan kalau dikatakan petugas sudah berangkat pada pukul 08.00 saya rasa masih kurang sesuai dengan kenyataan, bahwa pelayanan disini baru dimulai pada pukul 10.00. Hal tersebut juga dikuatkan dengan hasil observasi yang penulis lakukan dan mendapati bahwa memang pelayanan dimulai pada pukul 10.00 .

Hal diatas menunjukkan bahwa adanya persepsi yang berseberangan antara petugas dengan masyarkat. Untuk itu penulis melakukan uji keabsahan data dengan membandingkan data hasil pengamatan penulis dengan data hasil wawancara yang membuktikan bahwa petugas memang tidak langsung berangkat dari kantor pada pukul 08.00 setelah apel pagi dan pelayanan memang dimulai pada pukul 10.00. Jadi dapat dilihat bahwa dalam hal disiplin waktu masih belum sesuai dengan aturan, karena petugas tidak melaksanakan pelayanan dengan tepat waktu. Sementara disiplin ini sangat penting bagi suatu organisasi dalam menjalankan aktivitasnya, karena disiplin akan mempengaruhi prestasi organisasi.

\section{4) Sarana dan Prasarana}

Sarana dan prasarana ialah segala jenis peralatan, perlengkapan kerja dan fasilitas lain yang berfungsi sebagai 
alat utama/pembantu dalam pelaksanaan pekerjaan, dalam rangka mencapai tujuan. Berdasarkan temuan penelitian bahwa segala sarana dan prasana untuk menunjang pelayanan ini sudah tersedia secara memadai, mulai dari dana, tempat untuk pelayanan dan segala peralatan dan perlengkapan yang dibutuhkan untuk pelayanan. Dengan sarana dan prasarana yang tersedia secara memadai ini maka akan mempermudah dan menunjang proses pelaksanaan kegiatan.

Disisi lain masih terdapat permasalahan yaitu dari tingkat kesiapan nagari untuk melaksanakan pelayanan, seperti tidak tersedianya fasilitas tempat duduk dan pendingin ruangan bagi masyarakat, serta ruangan yang dirasa terlalu sempit. Jadi sarana dan prasarana adalah segala sesuatu yang dipakai sebagai alat dalam mencapai tujuan. Dengan memadainya sarana dan prasarana akan mempercepat proses pelaksanaan kegiatan dan dapat meningkatkan produktivitas. Selain itu sarana dan prasarana akan mempermudah pelaksanaan pelayanan dan menimbulkan rasa kenyamanan bagi dinas maupun masyarakat.

\section{5) Pengawasan}

Pengawasan merupakan proses pengamatan daripada pelaksanaan seluruh kegiatan untuk menjamin agar semua pekerjaan yang dilakukan berjalan sesuai dengan rencana yang telah ditentukan sebelumnya. Berdasarkan temuan penelitian bahwa dalam pelayanan kelilling online ini pengawasan dilakukan secara langsung oleh koordinator tim pelaksana, sekaligus penanggung jawab di lapangan jika ada hal yang perlu diputuskan atau diselesaikan. Sesuai dengan pendapat (Manullang, 2001) menyatakan pengawasan adalah proses
Email : jianfis.unp@gmail.com Vol.2 No.1 Maret 2019

untuk menetapkan pekerjaan apa yang sudah dilaksanakan, menilainya dan bila perlu mengoreksinya dengan maksud supaya pelaksanaan pekerjaan sesuai dengan rencana semula. Bahwa melalui pengawasan pelaksanaan tugas-tugas yang telah ditentukan dapat terlaksana sesui dengan rencana. Kemudian setelah pelayanan selesai dilakukan, akan dibuat laporan hasil kegiatan. Sehingga pengawasan dan pertanggungjawaban dalam pelaksanaan program jelas.

\section{c. Upaya Dinas Kependudukan dan Pencatatan Sipil dalam Meningkatkan Efektivitas Pelayanan Keliling Online}

Adapun upaya yang telah dilakukan oleh Dinas Kependudukan dan Pencatatan Sipil Kabupaten Tanah Datar dalam mengatasi permasalahan dalam pelaksanaan pelayanan keliling online adalah melakukan kerja sama dengan pihak nagari dalam melakukan himbauan, dimana sosialisasi sangat penting dalam sebuah program pemerintah karena melalui sosialisasi masyarakat yang menjadi sasaran diberlakukannya program tersebut dapat menyiapkan diri untuk menerima program pemerintah tersebut. Melalui himbauan yang juga memberikan informasi secara lengkap kepada masyarakat mengenai pelayanan, apa saja yang akan dilayani, persyaratan, waktu pelayanan, dan cara pelayanan.

Selain itu dinas telah melakukan kerja sama dengan berbagai pemangku kepentingan di lingkup Kabupaten Tanah Datar dalam rangka percepatan kepemilikan dokumen sekaligus untuk mengatasi permasalahan data-data masyarakat yang sering berbeda satu sama lain. Yaitu dengan mensyaratkan semua anggota keluarga yang ada dalam KK harus memiliki Akta Kelahiran, syarat untuk pendaftaran nikah dan penerbitan ijazah yang harus memiliki akta kelahiran. Kemudian untuk mengatasi permasalahan 
pada jaringan internet, dinas melakukan upaya pembelian peralatan penguat jaringan.

Dari paparan diatas sudah terlihat upaya dari dinas sebagai penanggung jawab program untuk meningkatkan efektivitas pelayanan keliling online ini, tetapi memang upaya yang dilakukan tidak mampu mengatasi seluruh permasalahan yang ada, sehingga masih ada permasalahan yang belum teratasi yang menyebabkan tingkat keberhasilan dar program tersebut masih rendah. Jadi ketika upaya-upaya tersebut telah dapat mengatasi seluruh permasalahan yang ada maka diharapkan permasalahan tersebut akan teratasi dan pelayanan keliling online ini dapat mencapai tujuan sehingga dapat dikatakan efektif.

\section{PENUTUP}

\section{A. Kesimpulan}

Berdasarkan hasil temuan dan hasil pembahasan yang telah penulis lakukan dapat ditarik kesimpulan bahwa pelaksanaan pelayanan keiling online belum dapat dikatakan efektif, dikarenakan masih belum dapat memenuhi kriteria dari efektifnya suatu program, diantaranya dilihat dari: a) Keberhasilan program, dalam hal ini banyak ditemui permasalahan dalam pelaksanaan pelayanan keliling online sehingga program sendiri belum berhasil dilaksanakan. b) Keberhasilan sasaran, sasaran yang telah ditetapkan tidak tercapai secara menyeluruh sehingga program tidak efektif. c) Kepuasan terhadap program, persepsi masyarakat dalam program ini menunjukkan bahwa masyarakat puas dengan adanya program ini. d) Tingkat input dan output, input yang diberikan dalam program ini dapat dikatakan sudah baik tetapi output yang menjadi tujuan utama tidak sesuai dengan harapan atau output program ini lemah dalam pencapaian tujuannya. e) Pencapaian tujuan menyeluruh, paparan-paparan diatas menunjukkan bahwa banyak terjadi
Email : jianfis.unp@gmail.com Vol.2 No.1 Maret 2019

permasalahan dan fakta di lapangan mengatakan bahwa pencapaian tujuan dalam program ini belum menyeluruh, hal tersebut menunjukan bahwa lemahnya pencapaian tujuan secara menyeluruh dan mengakibatkan kurang efektifnya program pelayanan keliling online ini.

Adapun faktor-faktor yang mempengaruhi efektivitas pelayanan keliling online dapat dilihat dari beberapa faktor sebagai berikut: a) Kualitas aparatur, dalam pelayanan ini petugas tidak dibekali dengan pendidikan dan pelatihan, dalam hal manajemen pengelolaan antara petugas yang pergi dan yang tinggal masih belum seimbang, selain itu target kinerja dalam pelayanan ini belum tercapai. b) Kompetensi administrator, kompetensi administrator sudah bagus ditandai dengan petugas yang sudah memiliki pengetahuan mengenai tugasnya, dan penempatan petugas sesuai bidang masing-masing. Kemudian sikap petugas dalam melayanani mesyarakat juga sudah baik. c) Disiplin, dalam kedisiplinan dalam hal ketepatan waktu pelayanan ini masih belum sesuai dengan aturan. d)Sarana dan prasarana, sarana dan prasaran untuk pelayanan sudah tersedia secara memadai, hanya saja permasalahan datang dari belum siapnya nagari untuk melakukan pelayanan. e) Pengawasan, pengawasan dilakukan secara langsung oleh ketua tim sekaligus penanggung jawab di lapangan. Sehingga pengawasan dan pertanggungjawaban dalam pelaksanaan program jelas.

Upaya Dinas Kependudukan dan Pencatatan Sipil dalam Meningkatkan Efektivitas Pelayanan Keliling Online berupa melakukan kerja sama dengan pihak nagari, membeli peralatan penguat jaringan dan melakukan kerja sama berbagai pemangku kepentingan di lingkup Kabupaten Tanah Datar, untuk lebih meningkatkan pencapaian tujuan pelayanan keliling online ini. Tetapi upaya tersebut masih belum mencapai efektivitas program ini. 
JMIAP

$\overline{\text { jmiap.ppj.unp.ac.id }}$

JURNAL ILMU ADMINISTRASI PUBLIK

Email : jianfis.unp@gmail.com

Vol.2 No.1 Maret 2019

\section{B. Saran}

Melihat dari kondisi yang ada di lapangan menunjukkan bahwa masih kurang efektifnya program pelayanan keliling online pada Dinas Kependudukan dan Pencatatan Sipil Kabupaten Tanah Datar maka penulis menyarankan: 1) Diharapkan kepada Dinas Kependudukan dan Pencatatan Sipil untuk melakukan sosialisasi kepada masyarakat tentang pelayanan keliling online. 2) Diharapakan kepada Dinas Kependudukan dan Pencatatan Sipil untuk meningkatkan kualitas sumber daya manusia, terutama dalam meningkatkan kesadaran masyarakat yaitu dengan memberikan arahan tentang pentingya kepemilikan dokumen kependudukan. 3) Diharapakan kepada Dinas Kependudukan dan Pencatatan Sipil untuk melengkapi pembelian peralatan penguat jaringan sehingga pelayanan dapat terlaksana di semua daerah.

\section{DAFTAR PUSTAKA}

Adaniah, R. (2016). Analisis Perkembangan Internet Broadband di Wilayah Perbatasan Provinsi Sulawesi Utara. Jurnal Penelitian Pos Dan Informatika, (6 Nomor 2), 202-203.

Campbell. (1989). Riset dalam Efektifitas Organisasi. Terjemahan Sahat

Simamora. Jakarta: Erlangga.

Hutapea, T. (2008). Kompetensi Plus. Jakarta: PT Gramedia Pustaka Utama.

Ibrahim, A. (2008). Teori dan Konsep Pelayanan Publik Serta Implementasinya. Bandung: Mandar Maju.

Jauhar, S. \&. (2013). Pengantar Teori dan Periaku Organisasi. Jakarta: Prestasi Pustaka.

Manullang, M. (2001). Manajemen Sumber Daya Manusia. Yogyakarta: BPUE.

Moleong, L. J. (2012). Metodologi Penelitian Kualitatif (Edisi Revisi). Bandung: Remaja Rosdakarya.

Mulyadi, D. (2016). Administrasi Publik untuk Pelayanan Publik. Bandung: Alfabeta.

Samsudin, M. (2014). Faktor-faktor yang berpengaruh terhadap Efektivitas Penyaluran Bantuan Sosial di Bagian Sosial Sekretariat Daerah Kabupaten Kutai Timur. eJournal Administrative Reform, 1 Nomor 2, 783-794.

Undang-Undang Nomor 24 Tahun 2013 tentang Administrasi Kependudukan. 